Witold Biaty $^{1}$

\title{
INNOWACYJNE ZASTOSOWANIE NARZĘDZI INŻYNIERII JAKOŚCI W PRZEMYŚLE WYDOBYWCZYM
}

\begin{abstract}
Streszczenie: Górnictwo węgla kamiennego, charakteryzuje się złożonością i specyfiką problemów związanych z użytkowaniem maszyn.

$\mathrm{Na}$ efektywność procesu wydobywania węgla kamiennego, istotny wpływ mają niezawodnie działające maszyny górnicze. Aby zapewnić większą efektywność oraz wydajność, należy znaleźć przyczyny najczęściej występujących w tym procesie awarii i skutecznie im przeciwdziałać. Przerwy spowodowane awaryjnością maszyn, przekładają się na efektywność całego procesu wydobywczego. Stąd w przemyśle górniczym poszukuje się nowych metod i narzędzi, które by istotnie wpływały na doskonalenie procesu wydobywczego w kopalniach.

W niniejszym artykule przedstawiono jedno z narzędzi inżynierii jakości stosowane w różnych gałęziach przemysłu - narzędziem tym jest diagram Pareto-Lorenza. Narzędzie to pozwoliło pogrupować przyczyny poszczególnych awarii, wykazać które z nich mają największe znaczenie i które powinny być w pierwszej kolejności usuwane.
\end{abstract}

Słowa kluczowe: awarie, maszyna, kopalnia, diagram Pareto-Lorenza

\section{Wprowadzenie}

Narzędzia zarządzania jakością służą do zbierania i przetwarzania danych związanych $\mathrm{z}$ różnymi aspektami jakości. Najczęściej wykorzystywane są do nadzorowania (monitorowania) całego cyklu produkcyjnego, począwszy od projektowania, konstruowania, wytwarzania, użytkowania, aż do kontroli po zakończonym procesie produkcyjnym.

W przemyśle wydobywczym, niewłaściwe zastosowanie maszyny/urządzenia do istniejących warunków geologiczno-górniczych, może skutkować wzrostem energochłonności procesu wydobywczego,

${ }^{1}$ dr hab. inż., prof. Pol. Śl., Politechnika Śląska, Wydział Organizacji i Zarządzania, Instytut Inżynierii Produkcji, e - mail: wbialy@polsl.pl 
przedwczesnym zużyciem, czy zwiększonymi przerwami w pracy, które są spowodowane awaryjnością (BIAŁY W. 2011a).

Firmy produkcyjne - w tym także kopalnie węgla kamiennego w sferze efektywności i bezpieczeństwa w procesie technologicznym, koncentrują wysiłki głównie na przygotowaniu procedur jakie należy przedsięwziąć w przypadku wystąpienia katastrof, awarii sprzętowych, czy też usuwania ich skutków. Zmieniająca się sytuacja gospodarcza na Świecie oraz w Polsce, konkurencja, a także coraz większe wymagania odbiorców (klientów) kopalni, wymuszają na kierownictwie kopalni poszukiwanie nowych sposobów na poprawę procesu produkcyjnego (wydobywczego) (BIAŁY W. 2011, ŁUCKI Z. 2005, SKOTNICKAZASADZIEŃ B., BIAŁY W. 2011).

W niniejszym artykule do oceny awaryjności maszyn/urządzeń górniczych, wykorzystano jedno $\mathrm{z}$ tradycyjnych narzędzi zarządzania jakością - diagram Pareto-Lorenza (PETER F. 2001, WOLNIAK R., SKOTNICKA B. 2007). Za pomocą tego graficznego obrazu można przedstawić zarówno względny jak i bezwzględny rozkład rodzajów błędów, problemów i przyczyn ich powstawania (KRAUZE K., KOTWICA K. 2007).

\section{Analiza problemu}

W przemyśle wydobywczym, diagram Pareto-Lorenza można wykorzystać do monitorowania i kontroli maszyn/urządzeń górniczych (kombajn ścianowy, przenośnik zgrzebłowy, przenośnik taśmowy, kruszarki oraz urządzenia zasilania i sterowania), które stanowią ważny element procesu wydobywczego w kopalni. Istotna jest tutaj ocena występujących przerw w pracy tych maszyn/urządzeń, czyli ich awaryjności i niezawodności. Ponadto istotne jest również wykazanie, które $\mathrm{z}$ wykrytych przyczyn powodujących przerwy $\mathrm{w}$ pracy (a spowodowane awaryjnością), powinny być wyeliminowane w pierwszej kolejności (SKOTNICKA-ZASADZIEŃ B., BIAŁY W. 2011, WANG Z., HUANG H-Z., DU X. 2009, WOLNIAK R., SKOTNICKA B. 2007). 


\subsection{Przerwy $w$ pracy spowodowane awariami ścianowego kompleksu kombajnowego}

Analiza przeprowadzona została na przykładzie jednej ściany, w kopalni należącej do Kompani Węglowej S.A., w której zainstalowany był kombajn wydobywczy, roboczo nazwany „AE” (PROJEKT TECHNICZNY ŚCIANY, DTR). Budowa modułowa (a taką budowę posiada kombajn „AE”), podstawowych zespołów kombajnów ścianowych, pozwala na dobór układu tych zespołów kombajnu zależnie od potrzeb technologicznych eksploatacji (np. kombajn jedno- lub dwugłowicowy albo jedno- lub dwuramionowy). Aktualnie górnictwo światowe wykazuje zapotrzebowanie na kombajny dwuraminowe $\mathrm{z}$ dwoma głowicami urabiającymi (BIAŁY W. 2011, KraUZE K., KotwiCA K. 2007).

Czas pracy analizowanej ściany od momentu jej uruchomienia do zakończenia eksploatacji, wyniósł 92 dni. Wszystkie przerwy w pracy ściany, powstałe w ciągu całego okresu wydobywczego ściany zostały zarejestrowane przez dyspozytora kopalni.

Jako miejsce wystąpienia awarii przyjęto urządzenie (maszynę) w którym wystąpiła przerwa w pracy. Miejsca awarii to:

- kombajn,

- przenośnik (ścianowy, podścianowy, taśmowy),

- kruszarka,

- obudowa,

- inne.

Wszelkie przerwy $\mathrm{w}$ pracy (przyczyny postojów przodka ścianowego) usystematyzowane zostały wg następującego algorytmu (BIAŁY W. 2011):

- uszkodzenia kombajnu,

- uszkodzenia przenośników (ścianowego, podścianowego oraz taśm odstawy oddziałowej),

- uszkodzenia obudowy oraz brak zasilania w medium,

- awarie górnicze (opad stropu, strzelanie wstrząsowe, pompowanie wody, rozbijanie brył, przekroczenie $\mathrm{CH}_{4}$, pobierka spąu), 
- inne przyczyny postojów (uszkodzony wąż wodny w ścianie, brak wody, brak napięcia elektrycznego).

Sumę wszystkich przerw w pracy kompleksu ścianowego przedstawia tabela 1 oraz diagram Pareto-Lorenza (rys. 1).

Tabela 1. Suma przerw w pracy kompleksu ścianowego

\begin{tabular}{|c|l|c|c|c|c|}
\hline Lp. & $\begin{array}{c}\text { Przerwy w pracy } \\
\text { elementu } \\
\text { kompleksu } \\
\text { ścianowego }\end{array}$ & $\begin{array}{c}\text { Liczba } \\
\text { przerw }\end{array}$ & $\begin{array}{c}\text { Lączny } \\
\text { czas } \\
\text { przerw } \\
\text { min }\end{array}$ & $\begin{array}{c}\text { Czas trwania } \\
\text { wszystkich } \\
\text { przerw } \\
\text { \% }\end{array}$ & $\begin{array}{c}\text { Skumulowany } \\
\text { czas } \\
\text { przerw } \\
\text { \% }\end{array}$ \\
\hline 1 & Kombajn & 67 & 6065 & 47 & 47 \\
\hline 2 & Przenośnik & 70 & 4920 & 39 & 86 \\
\hline 3 & Górnicza & 14 & 725 & 6 & 91 \\
\hline 4 & $\begin{array}{l}\text { Obudowa } \\
\text { zmechanizowana }\end{array}$ & 19 & 625 & 5 & 96 \\
\hline 5 & Inna & 13 & 500 & 4 & 100 \\
\hline Suma: & $\mathbf{1 8 3}$ & $\mathbf{1 2 8 3 5}$ & $\mathbf{1 0 0}$ & \\
\hline
\end{tabular}

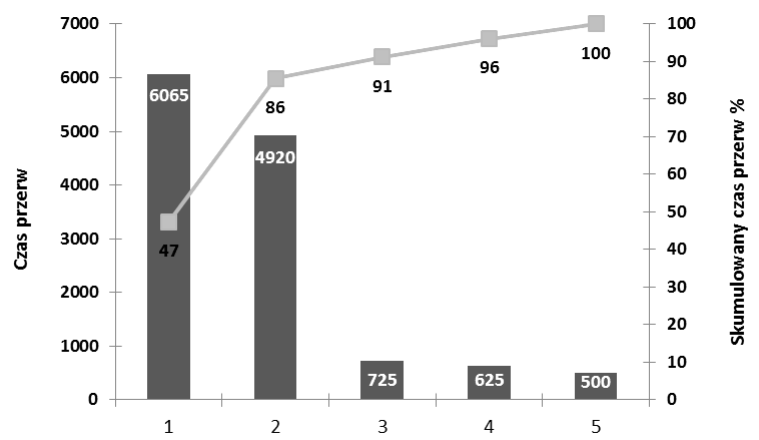

Rys. 1. Diagram Pareto-Lorenza dla kompleksu ścianowego

Tabela 1 ilustruje liczbę oraz czasy przerw w pracy poszczególnych składników kompleksu ścianowego. Pod względem liczby przerw wyraźnie widać, że największą awaryjność miały przenośniki, a tuż za nimi plasuje się kombajn (rys. 1). Natomiast uwzględniając łączny czas przerw, to na łączną sumę czasu przerw kompleksu ścianowego 
największy wpływ miały przerwy w pracy kombajnu, a następnie przenośników (KSIĄŻKI RAPORTOWE, RAPORTY DZIENNE).

$\mathrm{Z}$ diagramu Pareto-Lorenza (rys. 1) wynika, że przerwy w pracy kombajnu i przenośników powodują największe przestoje w pracy kompleksu ścianowego - ich łączna suma wynosi $86 \%$. Suma przerw zaliczonych do grupy: górnicze, obudowa zmechanizowana i „inne”, a które nie powstały $\mathrm{z}$ winy człowieka i nie są związane z zużyciem się poszczególnych elementów kompleksu ścianowego, stanowi tylko $14 \%$. Najbardziej awaryjnym elementem kompleksu ścianowego okazał się kombajn (47\%) - dlatego przeprowadzono szczegółową analizę awaryjności z podziałem na główne układy. Awarie poszczególnych układów kombajnu, podzielono następująco (BIAŁY W. 2011, SKOTNICKA-ZASADZIEŃ B., BIAŁY W. 2011):

- układ mechaniczny - wszystkie niesprawności mechaniczne na kombajnie, jak i jego wyposażenia (np. osłony górne, uzupełnianie oleju w układach mechanicznych),

- układ elektryczny - wszystkie niesprawności związane ze sterowaniem, brakiem napięcia na kombajnie (np. związane $\mathrm{z}$ doziemieniem na linii kombajnowej $\mathrm{w}$ ścianie, ponieważ każdorazowo po tej niesprawności uszkodzony był komputer na kombajnie, wymiana komputera, wymiana silników elektrycznych),

- układ hydrauliczny - wszystkie awarie związane z czynnościami jakie w kombajnie pełni zespół hydrauliczny (np. nieszczelności na przewodach, wymiana pompy czy siłownika, uzupełnianie oleju w zbiorniku hydraulicznym),

- inne - do których zaliczono: brak przepływu wody na kombajnie, wymiana zużytych noży na organach, wypadnięcie kombajnu z trasy BP.

Sumę awarii poszczególnych układów kombajnu obrazuje tabela 2 która przedstawia wpływ poszczególnych układów kombajnu na liczbę awarii, łączny czas awarii oraz czas trwania wszystkich awarii (wyrażony w \%). 
Tabela 2. Suma awarii uktadów kombajnu

\begin{tabular}{|c|l|c|c|c|c|}
\hline Lp. & $\begin{array}{c}\text { Miejsce wystapienia } \\
\text { awarii }\end{array}$ & $\begin{array}{c}\text { Liczba } \\
\text { awarii }\end{array}$ & $\begin{array}{c}\text { Laczny } \\
\text { czas awarii } \\
\text { min }\end{array}$ & $\begin{array}{c}\text { Czas trwania } \\
\text { wszystkich } \\
\text { awarii } \\
\text { \% }\end{array}$ & $\begin{array}{c}\text { Skumulowany } \\
\text { czas } \\
\text { awarii } \\
\text { \% }\end{array}$ \\
\hline 1 & Układ elektryczny & 39 & 3955 & 63 & 63 \\
\hline 2 & Układ mechaniczny & 18 & 1980 & 31 & 94 \\
\hline 3 & Inne & 7 & 300 & 5 & 99 \\
\hline 4 & Układ hydrauliczny & 3 & 105 & 1 & 100 \\
\hline \multicolumn{2}{|l}{ Suma: } & $\mathbf{6 7}$ & $\mathbf{6 3 4 0}$ & $\mathbf{1 0 0}$ & \\
\hline
\end{tabular}

Na diagramie Pareto-Lorenza (rys. 2) przedstawiono awaryjność kombajnu uwzględniając poszczególne układy kombajnu.

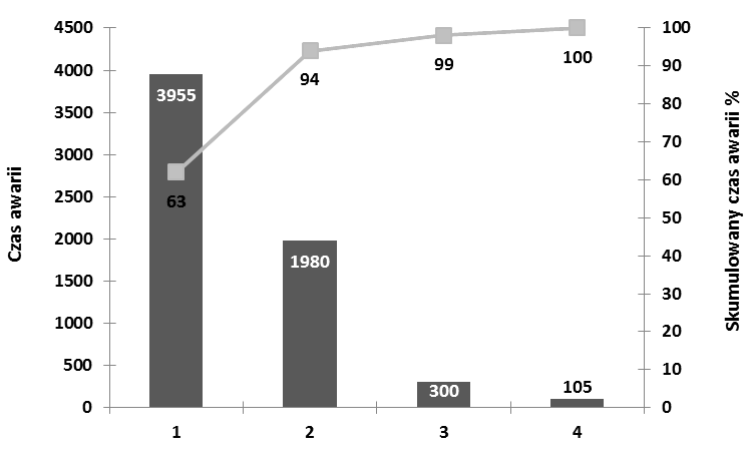

Rys. 2. Diagram Pareto-Lorenza dla kombajnu

Układ elektryczny kombajnu miał największy udział w przerwach w pracy w ogólnym czasie pracy (63\%), - awarie mechaniczne (31\%). Największą awaryjność wykazuje układ elektryczny, na co główny wpływ miały silniki elektryczne i ich wymiany, uszkodzenia komputera, uszkodzenia kabla kombajnowego w ścianie. Uszkodzenia mechaniczne to zerwanie sprzęgiełka przeciążeniowego w ciągniku posuwu. Awarie inne, to powtarzający się brak przepływu wody przez silniki elektryczne, który jest ograniczony poprzez osadzający się kamień.

Sumę łączną awarii na kombajnie według miejsca ich powstania przedstawia tabela 3 oraz diagram Pareto-Lorenza (rys. 3). 
Zeszyty Naukowe

$\mathrm{Nr}$ 1(4)

Quality. Production. Improvement

Tabela 3. Suma awarii kombajnu wedlug miejsca powstania

\begin{tabular}{|c|l|c|c|c|c|}
\hline Lp. & $\begin{array}{c}\text { Miejsce } \\
\text { wystąpienia } \\
\text { awarii }\end{array}$ & $\begin{array}{c}\text { Liczba } \\
\text { awarii }\end{array}$ & $\begin{array}{c}\text { Lączny } \\
\text { czas awarii } \\
\text { min }\end{array}$ & $\begin{array}{c}\text { Czas } \\
\text { trwania } \\
\text { wszystkich } \\
\text { awarii } \\
\text { \% }\end{array}$ & $\begin{array}{c}\text { Skumulowany } \\
\text { czas } \\
\text { awarii } \\
\%\end{array}$ \\
\hline 1 & $\begin{array}{l}\text { Ramię i organy } \\
\text { urabiające }\end{array}$ & 16 & 1970 & 34 & 34 \\
\hline 2 & $\begin{array}{l}\text { Ciągniki, układy } \\
\text { trakcyjne }\end{array}$ & 18 & 1640 & 28 & 62 \\
\hline 3 & $\begin{array}{l}\text { Zespół } \\
\text { elektryczny }\end{array}$ & 23 & 1390 & 24 & 86 \\
\hline 4 & Układ hydrauliki & 6 & 720 & 12 & 98 \\
\hline 5 & Rama (kadłub) & 4 & 165 & 2 & 100 \\
\hline Suma: & $\mathbf{6 7}$ & $\mathbf{5 8 8 5}$ & $\mathbf{1 0 0}$ & \\
\hline
\end{tabular}

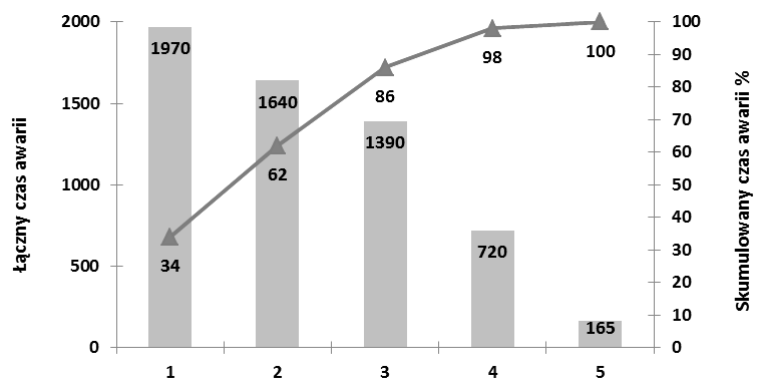

Rys. 3. Diagram Pareto-Lorenza awarii kombajnu

W podziale tym (tabela 3), na kombajnie zostały wydzielone podzespoły według miejsca wystąpienia awarii (BIAŁY W. 2011, SKOTNICKA-ZASADZIEŃ B., BIAŁY W. 2011):

- ramię $\mathrm{i}$ organy urabiające,

- ciągniki i układy trakcyjne,

- układ hydrauliki,

- rama,

- zespół elektryczny. 
Zeszyty Naukowe

Z przeprowadzonej analizy wynika, że najbardziej awaryjnym miejscem na kombajnie są ramiona, ciągniki oraz zespół elektryczny.

\subsection{Udzial przerw $w$ czasie dyspozycyjnym}

W trakcie eksploatacji ściany wystąpiły 183 przerwy w pracy których sumaryczny czas wyniósł 12835 minut (tabela 1.4). Łączny czas dyspozycyjny pracy kompleksu ścianowego wynosił 102120 min (KSIĄŻKI RAPORTOWE, RAPORTY DZIENNE). Tabela 4, przedstawia czas przerw oraz udział przerw w czasie dyspozycyjnym z wyszczególnieniem poszczególnych elementów kompleksu ścianowego.

Tabela 4. Udzial przerw w pracy ścianowego kompleksu kombajnowego (czas taczny oraz dyspozycyjny)

\begin{tabular}{|c|l|c|c|c|}
\hline Lp. & $\begin{array}{c}\text { Przerwy w pracy } \\
\text { elementu kompleksu } \\
\text { ścianowego }\end{array}$ & $\begin{array}{c}\text { Liczba } \\
\text { przerw }\end{array}$ & $\begin{array}{c}\text { Laczny czas } \\
\text { przerw } \\
\text { min }\end{array}$ & $\begin{array}{c}\text { Udzial przerw w czasie } \\
\text { dyspozycyjnym } \\
\%\end{array}$ \\
\hline 1 & Kombajn & 67 & 6065 & 5.94 \\
\hline 2 & Przenośnik & 70 & 4920 & 4.82 \\
\hline 3 & Górnicza & 14 & 725 & 0.71 \\
\hline 4 & $\begin{array}{l}\text { Obudowa } \\
\text { zmechanizowana }\end{array}$ & 19 & 625 & 0.61 \\
\hline 5 & Inna & 13 & 500 & 0.49 \\
\hline \multicolumn{2}{|l|}{ Suma: } & $\mathbf{1 8 3}$ & $\mathbf{1 2 8 3 5}$ & $\mathbf{1 2 . 5 7}$ \\
\hline
\end{tabular}

W tabeli 5 oraz na rysunku 4, przedstawione zostały awarie poszczególnych układów kombajnu, ich udział w czasie dyspozycyjnym z wyszczególnieniem: 
Zeszyty Naukowe

$\mathrm{Nr} 1(4)$

Quality. Production. Improvement

Tabela 5. Awarie uktadów kombajnu w czasie dyspozycyjnym (czas taczny $i$ czas dyspozycyjny)

\begin{tabular}{|c|c|c|c|c|}
\hline Lp. & $\begin{array}{c}\text { Miejsce wystapienia } \\
\text { awarii }\end{array}$ & $\begin{array}{l}\text { Liczba } \\
\text { awarii }\end{array}$ & $\begin{array}{c}\text { Laczny } \\
\text { czas awarii } \\
\text { min }\end{array}$ & $\begin{array}{c}\text { Udzial awarii w czasie } \\
\text { dyspozycyjnym } \\
\%\end{array}$ \\
\hline 1 & Układ elektryczny & 39 & 3955 & 3.87 \\
\hline 2 & Układ mechaniczny & 18 & 1980 & 1.94 \\
\hline 3 & Inne & 7 & 300 & 0.29 \\
\hline 4 & Układ hydrauliczny & 3 & 105 & 0.10 \\
\hline \multicolumn{2}{|c|}{ Suma: } & 67 & 6340 & 6.20 \\
\hline & $\begin{array}{c}\text { Układ } \\
\text { mechanicz } \\
1.94\end{array}$ & Inne & & $\begin{array}{l}\text { Układ } \\
\text { hydrauliczny } \\
0.10\end{array}$ \\
\hline
\end{tabular}

Rys. 4. Udzial awarii w czasie dyspozycyjnym

- miejsca wystąpienia awarii,

- liczby awarii,

- łącznego czasu trwania awarii (w minutach oraz procentach),

- udziału awarii w ogólnym czasie dyspozycyjnym.

Awarie kombajnu wyszczególnione wg miejsc powstania przedstawiono w tabeli 6.

Z przeprowadzonej analizy wynika, że najmniej awaryjnym elementem kombajnu jest rama (kadłub) kombajnu oraz układ hydrauliki. Pozostałe elementy powodują 85\% awarii (tabela 6). 
Tabela 6. Awarie kombajnu wedtug miejsca powstania (czas taczny oraz udzial w czasie dyspozycyjnym)

\begin{tabular}{|c|l|c|c|c|}
\hline Lp. & $\begin{array}{c}\text { Miejsce wystapienia } \\
\text { awarii }\end{array}$ & $\begin{array}{c}\text { Liczba } \\
\text { awarii }\end{array}$ & $\begin{array}{c}\text { Laczny } \\
\text { czas awarii } \\
\text { min }\end{array}$ & $\begin{array}{c}\text { Udzial awarii w czasie } \\
\text { dyspozycyjnym } \\
\text { \% }\end{array}$ \\
\hline 1 & $\begin{array}{l}\text { Ramię i organy } \\
\text { urabiające }\end{array}$ & 16 & 1970 & 1.93 \\
\hline 2 & $\begin{array}{l}\text { Ciągniki, układy } \\
\text { trakcyjne }\end{array}$ & 18 & 1640 & 1.61 \\
\hline 3 & Zespół elektryczny & 23 & 1390 & 1.36 \\
\hline 4 & Układ hydrauliki & 6 & 720 & 0.71 \\
\hline 5 & Rama (kadłub) & 4 & 165 & 0.16 \\
\hline Suma: & $\mathbf{6 7}$ & $\mathbf{5 8 8 5}$ & $\mathbf{5 . 7 7}$ \\
\hline
\end{tabular}

\section{Wyniki produkcyjne analizowanej ściany}

W ścianie zastosowany był czterozmianowy system pracy i potokowa forma organizacji robót z potokiem wybierkowym cyklicznym (KSIĄŻKI RAPORTOWE, RAPORTY DZIENNE). Zmiany 1, 2 i 3 były zmianami wydobywczo-produkcyjnymi, zaś zmiana 4 była zmianą konserwacyjnoremontową.

Zagrożenia naturalne jakie występowały w eksploatowanej ścianie były następujące:

zagrożenie metanowe

III kategoria, zagrożenie wodne I stopień, zagrożenie tąpaniami nie występowało, zagrożenie pożarem endogenicznym III grupa samozapalności, zagrożenie uskoków i zrzutów skał $0,3 \mathrm{~m}$ do $2,7 \mathrm{~m}$

Wykaz dni roboczych $\mathrm{w}$ analizowanej ścianie przedstawiał się następująco (RAPORTY DZIENNE):

- maj -7 ,

- czerwiec-20,

- lipiec-23,

- sierpień -21 ,

- wrzesień -21 . 
Zeszyty Naukowe

\section{Quality. Production. Improvement}

Łączna ilość dni roboczych w analizowanej ścianie wyniosła 92 mała ilość dni roboczych w maju (7), wynikała z rozruchu ściany.

Analizę wyników produkcyjnych ściany na przestrzeni analizowanego okresu w rozbiciu dobowym i miesięcznym przedstawia tabela 7 oraz wykres (rys. 5).

Tabela 7. Wydobycie dobowe i miesięczne kopaliny oraz czystego wegla

\begin{tabular}{|c|l|c|c|c|c|}
\hline \multirow{2}{*}{ Lp. } & \multirow{2}{*}{ Miesiąc } & \multicolumn{2}{|c|}{ Wydobycie Mg/dobe } & \multicolumn{2}{c|}{ Wydobycie Mg/miesiąc } \\
\cline { 3 - 6 } & $\begin{array}{c}\text { Catkowite } \\
\text { wydobycie }\end{array}$ & Czysty węgiel & $\begin{array}{c}\text { Catkowite } \\
\text { wydobycie }\end{array}$ & Czysty węgiel \\
\hline 1 & maj & 3131 & 2205 & 21919 & 15417 \\
\hline 2 & czerwiec & 4280 & 3060 & 85580 & 61209 \\
\hline 3 & lipiec & 4326 & 3120 & 99957 & 71701 \\
\hline 4 & sierpień & 4838 & 3717 & 101604 & 70552 \\
\hline 5 & wrzesień & 4485 & 3537 & 94184 & 74268 \\
\hline \multicolumn{2}{|c|}{ Średnia: } & $\mathbf{4 2 1 2}$ & $\mathbf{3 1 2 8}$ & $\mathbf{8 0 6 4 9}$ & $\mathbf{5 8 6 2 9}$ \\
\hline
\end{tabular}

Źródto: KSIĄŻKI RAPORTOWE, RAPORTY DZIENNE

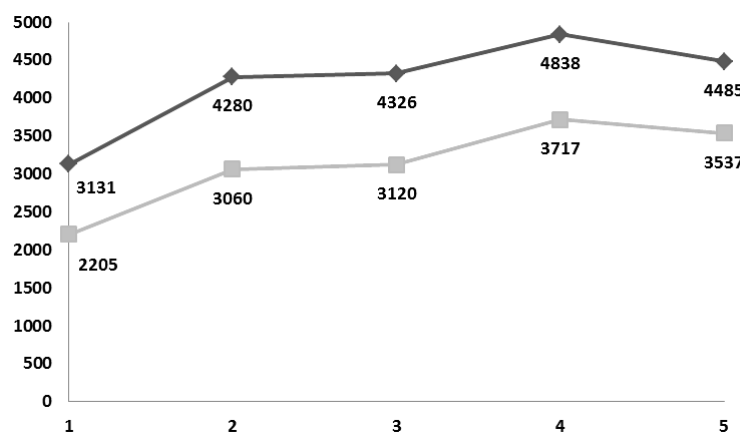

Rys. 5. Wydobycie dobowe kopaliny oraz czystego wegla

Tabela 7 oraz wykres (rys. 5) przedstawia średnie wydobycie całkowite kopaliny oraz węgla $\mathrm{w}$ poszczególnych miesiącach w rozbiciu na poszczególne miesiące uzyskane wyniki były zróżnicowane. Z wykresu (rys. 5) wynika również, że ściana dość znacznie przekroczyła założony wynik produkcyjny (3000 Mg/dobę). 
W miesiącu maju średniodobowe wydobycie dość znacznie różniło się od pozostałych miesięcy, co wynikało z uruchomienia ściany. Natomiast najwyższe średniodobowe wydobycie osiągnięte zostało $\mathrm{w}$ miesiącach sierpień oraz wrzesień. Na uzyskane miesięczne wyniki istotny wpływ miały awarie kompleksu ścianowego.

W rzeczywistości można było uzyskać lepszy wynik produkcyjny, jednak awarie kompleksu ścianowego (w tym głównie kombajnu $47.30 \%$ wszystkich awarii kompleksu ścianowego) oraz utrudnienia geologiczno-górnicze zaniżyły wyniki produkcyjne.

\section{Podsumowanie}

W czasie trwania eksploatacji ściany (92 dni) awarie które zostały zarejestrowane przez dyspozytora spowodowały 183 przerwy w pracy kompleksu ścianowego, o łącznym czasie trwania 12835 minut. Operatywny czas pracy jednej zmiany był równy $330 \mathrm{~min}$ tj. 5,5 godziny - ściana pracowała w systemie 4 zmianowym. W ujęciu zmianowym, wydobycie $\mathrm{z}$ analizowanej ściany $\mathrm{w}$ wyniku awarii uległo „wydłużeniu” o prawie 39 zmian (12835:330 = 38,9 zmiany).

Analizując elementy kompleksu ścianowego (tabela 1), najbardziej awaryjnym urządzeniem okazał się kombajn, w odniesieniu do czasu przerw $(47.30 \%)$ - miał największy wpływ na przerwy w pracy.

Wśród wydzielonych układów kombajnu, rozkład awarii przedstawiał się następująco:

- Układ elektryczny - awarie stanowiły 62.40\% (3955 min). Liczba awarii wyniosła 39, co w sumie spowodowało wydłużenie pracy kompleksu o 65.90 godz. - na usunięcie tych awarii potrzebnych było 12 zmian.

- Układ mechaniczny - $31.20 \%$ całkowitego czasu przerw. Łączny czas przerw to 1980 min. - czas potrzebny na ich usunięcie to 6 zmian wydobywczych.

- Inne oraz awarie układu hydraulicznego wyniosły odpowiednio: $4.70 \%$ oraz $1.70 \%$ wszystkich przerw spowodowanych przez awarie. 
Można uznać, że te awarie nie miały wpływu na wydłużenie czasu pracy ściany.

Analizując awarie kombajnu (tabela 6), można zauważyć trzy główne miejsca ich powstawania, a mianowicie:

1. Ramię i organy urabiające $-33.50 \%$ ogólnego czasu awarii.

2. Ciągniki, układy trakcyjne $-27.90 \%$ czasu awarii.

3. Zespół elektryczny $-23.60 \%$ czasu ogólnego awarii.

Pozostałe awarie (układ hydrauliki oraz kadłub) stanowią łącznie 15\% ogólnego czasu awarii. Wynika stąd, że awarie (poz. 1-3) spowodowały łącznie 5000 min przerw w pracy (85\%) co wpłynęło na „wydłużenie” czasu pracy ściany o 9 zmian wydobywczych.

Suma czasów przestoju kombajnu w całkowitym czasie przerw to ponad 11 zmian wydobywczych $(6065: 330=11$ zmian), wiąże się to $\mathrm{z}$ trudnymi warunkami pracy, jakie ma ten element kompleksu ścianowego.

Aby więc nie dochodziło do częstych postojów (67), pracownicy związani z obsługą kombajnu winni być często szkoleni w zakresie obsługi i eksploatacji, w szczególności w takich zagadnieniach jak:

- przeznaczenie, budowa oraz zasada działania i zastosowanie systemu sterowania oraz diagnostyki,

- zasady działania i instalowania czujników systemu,

- struktura, budowa i zasada działania części składowych i podzespołów,

- metody instalacji, uruchamiania oraz obsługi,

- diagnostyki i analizy przyczyn awarii i ich usuwania,

- wytyczne eksploatacji,

- wymagania BHP.

$\mathrm{W}$ tej grupie awarii człowiek nie jest bezpośrednią przyczyną, ale może skutecznie zapobiegać powstawaniu niektórych $\mathrm{z}$ tych awarii. Można zmniejszyć czas ich usunięcia poprzez częste szkolenia personelu dotyczące usuwania skutków awarii. Należy również przeprowadzać szkolenia związane $\mathrm{z}$ właściwą konserwacją urządzeń (maszyn) co przyczyni się do przedłużenia bezawaryjnej pracy urządzeń (maszyn). 
Przeprowadzona analiza wyników produkcyjnych potwierdza osiągnięcie założonych celów produkcyjnych, pomimo zaistniałych awarii. $\mathrm{Z}$ tabeli 7 oraz wykresu (rys. 5) wynika, że ściana (mimo dużego nachylenia pokładu) (PROJEKT TECHNICZNY ŚCIANY) średnio wydobywała $3128 \mathrm{Mg} /$ dobę, czystego węgla, czyli zrealizowany został założony plan wydobycia wynoszący $3000 \mathrm{Mg}$ /dobę.

Poprzez poprawę efektywności eksploatowania, która w praktyce przekłada się na wzrost (wydłużenie) zdatności maszyn i urządzeń, ograniczenia awarii i przestojów oraz właściwą organizację i realizację prac obsługowych i konserwacyjnych, możliwe jest utrzymanie ciągłości produkcji, zwiększenie wydajności i poprawa jakości produkowanych wyrobów oraz ograniczenie kosztów eksploatacji maszyn i urządzeń, a co za tym idzie ograniczenie kosztów produkcji i produktu.

Artykut jest wynikiem pracy statutowej o symbolu BK-223/ROZ-3/2015 pt. "Znaczenie inżynierii produkcji $w$ rozwoju innowacyjnych produktów i ustug", realizowanej $w$ Instytucie Inżynierii Produkcji na Wydziale Organizacji i Zarządzania Politechniki Ślaskiej.

\section{LITERATURA:}

1. BIAŁY W.: 2011 „Górnictwo węgla kamiennego - wybrane problemy funkcjonowania". Monografia. Wydawnictwo PKJS Gliwice.

2. BIALY W.: 2011a The selection of optimal method determining mechanical properties of coal layers. Management Systems in Production Engineering No. 4

3. FRANIK T. 2009 Monitorowanie podstawowych parametrów procesów produkcyjnych w kopalni węgla kamiennego. Komputerowo zintegrowane zarządzanie. Praca zbiorowa pod red. R. Knosali, Opole: Oficyna Wydawnicza PTZP.

4. KRAUZE K., KotwiCA K.: 2007 Selection and underground tests of the rotary tangential cutting picks used in cutting heads of the longwall and roadway miners. Archives of Mining Sciences vol 52. No. 2.

5. ŁUCKI Z:: 2005 Zarzadzanie $w$ górnictwie naftowym $i$ gazownictwie. Kraków: Wydawnictwo Universitas. 
6. PETER F.: 2001 Rethinking Pareto analysis maintenance applications of logarithmic scatterplots. Journal of Quality i Maintenance Engineering, 4(7).

7. SKOTNICKA-ZASADZIEŃ B., BIAŁY W.: 2011 An analysis of possibilities to use a Pareto chart for evaluating mining machines' failure frequency. Maintenance and Reliability No. 3.

8. WANG Z., HuANG H-Z., DU X.: 2009 Projektowanie niezawodności z wykorzystaniem kilku strategii utrzymania. Maintenance and Reliability, No. 4.

9. WOLNIAK R., SKOTNICKA B.: 2007 Metody i narzędzia zarządzania jakościq - teoria i praktyka. Gliwice. Wydawnictwo Politechniki Śląskiej.

10. Książki raportowe działu Głównego Mechanika ds. dołu.

11. Raporty dzienne dyspozytora głównego kopalni.

12. Projekt Techniczny Ściany pokład 409/1.

13. DTR Kombajnu Ścianowego „AE”. 